on "The Rise of Man," were, in 2800 B.c., able to coast round Arabia and up the Red Sea to Suez. Why should they not be able a few hundred years later to coast round Africa and Spain and up the Atlantic to Britain?

In 2800 B.c., according to the same authority, the Akkadians were acquainted with silver, gold, bronze, and copper.

One of the most recent theories of the stone circlesthat of Sir Norman Lockyer-is that they were astronomical observatories, by means of which the ancient priests made observations of the sun and stars, and were thereby able to regulate the calendar, to foretell and prepare for the festival seasons of the year, and to tell the time at night.

This theory is in remarkable agreement with the anthropometrical conclusions which I have just submitted to you, for the Akkadians were apparently the first inventors of astronomy. Gudea, the Akkadian prince, who lived about 2800 B.c., has left a stepped pyramid with an observatory on the top. The Akkadians were the astronomical race at the dawn of civilisation, and apparently the ideas of an astronomical race have been embodied in our British stone circles.

\section{THE BRITISH ORNITHOLOGISTS' UNION.}

THE British Ornithologists' Union celebrated its fiftieth anniversary in the rooms of the Zoological Society on Wednesday, December 9. A special meeting was called for the occasion, the president of the union, Dr. F. D. Godman, F.R.S., occupying the chair, and reading an address on the history of the union from its foundation. The idea of forming this society was due, he remarked, to the late Prof. Newton, and was first mooted in his rooms at Cambridge during 1858 ; but it appears finally to have taken shape when, in the following year, at the meeting of the British Association at Leeds, the opportunity was seized of calling together a number of the ornithologists there assembled. The details of the constitution of the union appear to have been then discussed, and a few months later took their final shape. Limited for the first few years of its existence to twenty members, it was at last found expedient to remove this restriction. To-day more than four hundred members are on the roll. From the first it was decided to start a journal, and the name chosen for this was that of the sacred bird of Egypt, the Ibis. The history of the birth and growth of this now celebrated journal was traced later by Dr. Sclater, its first and present editor. After the addresses by the president and Dr. Sclater, gold medals were presented to the four survivors of the original founders, Dr. Godman, Mr. Percy Godman, Dr. Sclater, and Mr. W. H. Hudleston. This pleasant ceremony was followed by an appeal to the members from Mr. Ogilvie Grant, of the British Museum (Natural History), wherein he urged that the union should commemorate its jubilee by sending an expedition to explore the Charles Louis Mountains of New Guinea, probably one of the richest unexplored zoological regions of the world, and this was unanimously agreed upon. The union, of course, could not find the whole of the money necessary for such an undertaking, but a considerable sum has been promised by others interested in this work. The meeting was brought to a conclusion by a dinner held at the Trocadero Restaurant, after which Mr. Boyd Alexander gave a lecture on his recent journey across Africa, and this was followed by a kinematograph exhibition of pictures of bird life.

At a special general meeting, held in the same week, the union considered the report of a committee on a motion brought forward by Mr. H. F. Witherby at the last annual meeting. It was then proposed that the taking or killing of certain birds, or the taking of any egg of certain birds, or the purchase of any such egg knowing it to have been taken in the British Islands by any member of the union, should involve the removal of his name from the list of members. The prohibition with regard to birds was to applv all the year round to the bearded-top golden oriole, hoopoe, marsh harrier, hen harrier. Montagu's harrier, common buzzard, golden eagle, white-tailed eagle, kite, hobby, osprey, common bittern, spoonbill, Kentish plover, avocet, and chough. To the crested tit, snow-bunting, grey-leg goose, dotterel, red-necked phalarope, ruff, whimbrel, black tern, Sandwich tern, roseate tern, great skua, black-throated diver, red-throated diver, and greenshank it was only to apply for the breeding season, but it was to be in force for the eggs of any of the species named. After discussion, it was agreed that if in the opinion of the committee any member shall have personally assisted in or connived at the capture or destruction of any bird, nest, or eggs in the British Isles, by purchase or otherwise, likely in the opinion of the committee to lead to the extermination or serious diminution of that species as a British bird, steps shall be taken, after due inquiry, to remove the offender's name from the list of members.

\section{UNIVERSITY AND EDUCATIONAL INTE LLIGENCE.}

The Most Rev. Dr. Walsh, Roman Catholic Archbishop of Dublin, has been elected Chancellor of the new National University of Ireland.

ThE Berlin correspondent of the Daily Chronicle announces that Prof. Ernst Haeckel, professor of zoology at the University of Jena, is about to retire into private life after forty-eight years' professorial activity. $\mathrm{He}$ will be succeeded by Prof. L. Plate, professor of zoology in the Berlin Agricultural High School.

University College, Reading, has issued a special list of courses in poultry keeping to be given there, with practical training at the college poultry farm, Theale, inclusive of theoretical and practical teaching in this subject. Additional lectures are given by members of the staff on zoology, soils, manures and pastures, chemistry of foods, and bookkeeping.

THE current number of the Empire Review includes an article on the Imperial College of Science and Technology by Dr. Henry T. Bovey, F.R.S., the rector of the college. After giving a brief historical résume of the growth of the Royal College of Science, the Royal School of Mines, and the Central Technical College, Dr. Bovey explains the work of the Departmental Committee appointed by the Board of Education in IgO4, the issue of the charter of July 8, 1907, creating the Imperial College, and the constitution of the governing body. The aims and objects of the new college are then dealt with, and in this part of his article the rector follows very closely the able address he delivered to the students at the opening of the session last October, which was published in full in our issue for October 15 last (vol. lxxviii., p. 613).

THE Department of Agriculture and Technical Instruction for Ireland has arrived at an agreement with the Commissioners of National Education in Ireland for providing means for the training of national-school teachers in elementary experimental science and domestic economy as part of local schemes of technical instruction. The Commissioners are prepared to recognise teachers, who hold certificates of satisfactory attendance at classes approved by the Department, as qualified to give instruction in the subjects named. The Department has circulated copies of the regulations which will govern the classes to be inaugurated and syllabuses of courses of instruction in both subjects. Each course extends over three years, is well graduated, and skilfully adapted to the needs of teachers in elementary schools. The third year's course in elementary experimental science provides instruction in rural economy, and it is so framed that in a few years' time Ireland should possess elementaryschool teachers able and desirous of basing the science teaching of country schools upon the everyday surroundings and experiences of the children.

THe annual prize distribution at the Sir John Cass Technical Institute was held on Wednesday, December 16 , when the chair was taken by Sir Owen Roberts, chairman of the governing body. The prizes were distributed by $\mathrm{Mr}$. Lewis F. Day, after delivering an address, in which he dealt with the mutual dependence of design in art and craft work and their relation to trade, and concluded with NO. 2043, VOL. 79] 